\title{
CORERSPONDENOF.
}

THE RIVER OF THE BALTIC.

Sir,-In reference to Professor Bonney's letter in the Grologroan Magazine for this month, will yon allow me to say that some light on the origin of the remarkable channel which follows the southern zoast of Norway seems to be thrown by reference to Dr. Kjerulf's map of the ice-strim and course of the erratic blocks in his work, "Geologie des Süd. und Mit. Norwegen," 'Taf. vi, p. 25, from which it will be seen that the erratic blocks have been carried for long listances westwards along the path indicated by the deep chamnel between the Christiania Fiord and Stavanger. On the other hand the land striæ point southwards; so that the direction of the ice-drift on the submerged portion is perpenticular to the general course of the movement of the ice on the land to the north. The question arises, were the movements of the ice on the land southwards, and that of the ice westwards, on the coast, contemporaneous; or do they represent different epochs of the Pleistocene period? If contemporuneous, the land-ice must have been diverted from its normal course by some opposing barrier; if referable to different epochs, the erratic blocks may have been carried by floating ice along with the trend of the current passing outwards through the Skager Rak; or they may have been carried by land-ice duringr an epoch of elevation, while the ice itself, in the form of a great glacier, may have ploughed out the loose material with which the whole floor of the Skager Rak may once have been covered, and piled it up on either hand as it moved along. The origin of this channel is certainly a difficult problem; but I feel satisfied it can only be solved by considerations zonnected with the movements of the land-ice over the unsubmerged sortions and those of the submerger.

June, 1899.

\section{THE GEOLOGY OF THE COUNTRY AROUND CARLISLE.}

Sir,-In your review of Mr. Holmes' Memoir of the Geology of the Country around Carlisle, you state that "the conclusions at which Mr. Holmes arrived were not those to which Mr. Aveline and the ate Sir Andrew Ramsay could agree." As I have never seen Mr. Holmes' Memoir, or knew that it was published, I do not know what these conclusions are. But I have always maintained that no part of the St. Bees Sandstone represented any part of the Bunter Sandstones of the Midland or Northern Counties, but was more orobably represented by what has been mapped in Yorkshire as ihe "Middle Marls and Sandstone" and the "Upper Magnesian limestone" (a very misleading name). I have never stated that here could be no passage from the Permian up into the Trias, but ust the reverse; I have also stated that there was a much greater sonformity between the so-called Middle Marls and Upper Limestone (which are classed with the Permian in Yorkshire) with he Bunter Sandstone than with the Lower Magnesian Limestone jelow them. My anxiety is not so much for the retention of names, 